\title{
MENINGKATKAN KEMAMPUAN PEMECAHAN MASALAH MATEMATIS DAN SELF-CONCEPT CALON GURU DI KABUPATEN KARAWANG MELALUI PENDEKATAN OPEN-ENDED
}

\author{
Hendra Kartika \\ Universitas Singaperbangsa Karawang \\ E-mail: hendra.kartika@staff.unsika.ac.id
}

\begin{abstract}
:
This study aims to investigate open-ended learning approach in improving undergraduate students' mathematical problem-solving ability and self-concept toward linear algebra subject. Population in this study is mathematics education students FKIP Unsika in four semesters that takes linear algebra courses while the sample is two classes became experiment class and control class. The research design that used in this study is non-equivalent control group design. Results show that undergraduate students' mathematical problem-solving ability and self-concept who followed openended learning approach were fostered significantly compared to undergraduate students' who received conventional teaching method.
\end{abstract}

Keywords: mathematical problem solving, open-ended approach, self-concept.

\section{PENDAHULUAN}

Pendidikan pada tingkat perguruan tinggi merupakan pendidikan yang bersifat terbuka. Terbuka terhadap pola pikir yang baru, ide-ide baru, metode, pendekatan dan teknik pendidikan yang baru. Pelaku pendidikan khususnya mahasiswa dan dosen dituntut terhadap penerapan pola-pola dan ide-ide tersebut. Tuntutan itu muncul ketika mahasiswa dan dosen melakukan proses belajar-mengajar di kelas.

Proses belajar-mengajar di tingkat perguruan tinggi pada dasarnya sama dengan proses belajar-mengajar di tingkat pendidikan dasar dan menengah. Perbedaannya terdapat pada ruang lingkup, kedalaman materi dan tahap perkembangan intelektual peserta didiknya. Namun, untuk tujuan pembelajaran bisa saja berbeda, hal ini terkait dengan otonomi perguruan tinggi yang diberikan kebebasan dan kemandirian dalam pengelolaan pendidikan. Khususnya struktur kurikulum dan visi-misi perguruan tinggi.
Selain itu, mahasiswa adalah predikat tertinggi yang diberikan bagi peserta didik yang sedang menempuh pendidikan di perguruan tinggi. Mahasiswa diharapkan mampu menyelesaikan berbagai masalah yang dihadapi dengan menggunakan metode yang tepat. Pada beberapa permasalahan khususnya yang berhubungan dengan matematika, adakalanya dihadapkan dengan lebih dari satu metode penyelesaian. Mahasiswa diharapkan mampu mengidentifikasi masalah tersebut dengan menerapkan metode penyelesaian yang tepat.

Namun pada kenyataannya, hasil observasi di lapangan menunjukkan bahwa masih ada mahasiswa yang kebingungan ketika dihadapkan dengan permasalahan yang mempunyai lebih dari satu metode atau lebih dari satu penyelesaian. Selain itu, meskipun dasar-dasar matematika yang digunakan di Universitas sebagian besar telah diberikan di jenjang sebelumnya (SMU), tetapi dari penelitian Nagikondor (Nuryati, 2009:3) dijelaskan bahwa pada kenyataan di 
lapangan kemampuan matematika mahasiswa yang diberikan di tingkat perguruan tinggi harus dilakukan pengulangan lagi dalam pemberian materi tersebut meskipun hanya disampaikan sekilas. Berdasarkan kondisi tersebut, tentu hal ini menjadi faktor yang lain yang menyebabkan mahasiswa lemah dalam kemampuan memecahkan masalah matematika khususnya masalah yang bersifat terbuka (open-ended problem), yaitu masalah matematika yang mempunyai banyak teknik penyelesaian atau mempunyai banyak solusi yang berbeda.

Berdasarkan permasalahan tersebut, maka perlu menerapkan pola pembelajaran melalui pendekatan yang berbeda. Pembelajaran yang mampu meningkatkan kemampuan pemecahan masalah matematis mahasiswa, khususnya masalah matematika yang bersifat terbuka. Salah satunya adalah pembelajaran matematika melalui pendekatan Open-ended.

Selain kemampuan memecahkan masalah matematika, terdapat aspek psikologi yang turut memberikan kontribusi terhadap keberhasilan seseorang dalam menyelesaikan tugas dengan baik. Aspek psikologis tersebut salah satunya adalah self-concept. Ritandiyono dan Retnaningsih (Rahman, 2012:6) menyatakan Selfconcept bukan merupakan faktor yang dibawa sejak lahir, melainkan faktor yang dipelajari dan terbentuk melalui pengalaman individu dalam berhubungan dengan orang lain. Oleh karena pandangan individu tentang dirinya dipengaruhi oleh bagaimana individu mengartikan pandangan orang lain tentang dirinya.

Sudah menjadi suatu kondisi yang alami bahwa setiap manusia memiliki kemampuan yang berbeda-beda. Hal ini dapat terjadi karena manusia memiliki kemampuan merefleksi dirinya sendiri yang disebut "self-concept" (R. B. Burns dalam Rahman, 2012:6).

Berdasarkan permasalahan di atas, maka diadakan penelitian yang terkait dengan kemampuan pemecahan masalah matematis dan self-concept dengan pembelajaran melalui pendekatan open-ended terhadap mahasiswa. Pembelajaran matematika melalui pendekatan open-ended ini diharapkan mampu meningkatkan kemampuan pemecahan masalah dan self-concept mahasiswa calon guru di Kabupaten Karawang.

\section{Kemampuan Pemecahan Masalah}

Menurut Mayer (Kirkley dalam Widjajanti, 2009:404) pemecahan masalah merupakan suatu proses banyak langkah dengan si pemecah masalah harus menemukan hubungan antara pengalaman (skema) masa lalunya dengan masalah yang sekarang dihadapinya dan kemudian bertindak untuk menyelesaikannya. pemecahan masalah merupakan bentuk pembelajaran yang dapat menciptakan ide baru dan menggunakan aturanaturan yang telah dipelajari terdahulu untuk membuat formulasi pemecahan masalah (Polya dalam Muchlis, 2012:137).

\section{Self-Concept}

Menurut Hurlock (Rahman, 2012:4), self-concept merupakan gambaran seseorang mengenai dirinya sendiri yang meliputi fisik, psikologis, sosial, emosional, aspirasi dan prestasi yang telah dicapainya. Segi fisik meliputi penampilan fisik, daya tarik dan kelayakan. Sedangkan segi psikologis meliputi pikiran, perasaan, penyesuaian keberanian, kejujuran, kemandirian, kepercayaan serta aspirasi. Menurut Fuhrmann (Widodo, 2006:3), 
self-concept adalah konsep dasar tentang diri sendiri, pikiran dan opini pribadi, kesadaran tentang apa dan siapa dirinya, dan bagaimana perbandingan antara dirinya dengan orang lain serta bagaimana idealisme yang telah dikembangkannya.

\section{General Self-Concept} (Widodo, 2006:3) dan kawan-kawan yang digunakan sebagai landasan teori skala self-concept dalam penelitian ini dapat digambarkan sebagai berikut:

Academic Self-Concept

Non-Academic Self-Concept

\section{Evaluation of Behaviours in Spesific Situation}

Gambar 1. Model self-concept oleh Shavelson, Hubner dan Stanton (Widodo, 2006:4)

\section{Pendekatan Open-Ended}

Japar (Uhti, 2011:511) menyatakan bahwa pendekatan open-ended dalam pembelajaran matematika merupakan suatu pendekatan yang memungkinkan mahasiswa untuk mengembangkan pola pikirnya sesuai dengan minat dan kemampuan masing-masing. Hal ini disebabkan karena pada pendekatan open ended formulasi masalah yang digunakan adalah masalah terbuka. Masalah terbuka adalah masalah yang diformulasikan memiliki multi jawaban (banyak penyelesaian) yang benar. Pendekatan open-ended dalam pembelajaran matematika bertujuan menciptakan suasana pembelajaran agar mahasiswa memperoleh pengalaman dalam menemukan sesuatu yang baru melalui proses pembelajaran secara serempak dalam pemecahan masalah (Hudiono dalam Lambertus, 2013:75).

\section{METODE PENELITIAN}

Penelitian ini merupakan penelitian kuasi-eksperimen karena pada penelitian ini subyek tidak dikelompokkan secara acak tetapi dipilih berdasarkan kelompokkelompok yang sudah terbentuk secara alamiah.

Desain penelitian yang digunakan adalah non-equivalent control group design. Desain ini dipilih karena subjek tidak dikelompokkan secara acak, tetapi menerima keadaan subjek seadanya. Pada penelitian ini juga terdapat pretes, perlakuan yang berbeda dan postes.

Populasi dalam penelitian ini adalah seluruh mahasiswa semester 4 pendidikan matematika yang mengikuti perkuliahan aljabar linear. Sedangkan sampel penelitiannya adalah 31 mahasiswa kelas pagi yaitu kelas A yang dijadikan sebagai kelas kontrol dan 31 mahasiswa kelas siang yaitu kelas B yang dijadikan sebagai kelas eksperimen. Sampel penelitian ini terdiri dari dua kelas yang dipilih berdasarkan purpossive sampling.

Data dalam penelitian ini diperoleh dengan menggunakan dua instrumen, yang terdiri dari: (1) Soal tes kemampuan pemecahan masalah matematis; (2) Menggunakan skala Likert mengenai self-concept mahasiswa terhadap pembelajaran. Data berupa hasil tes kemampuan pemecahan masalah matematis dianalisis secara kuantitatif dengan menggunakan uji statistik. Untuk menentukan uji statistik yang akan digunakan, terlebih dahulu diuji normalitas data dan homogenitas varians. Sedangkan data penelitian nontes berupa skala self-concept di analisis 
untuk mengetahui sikap mahasiswa terhadap pembelajaran matematika melalui pendekatan open-ended. Langkah yang dilakukan adalah memberikan skor pada setiap butir pernyataan siswa dengan berpedoman pada skala sikap model likert.

\section{HASIL PENELTIAN DAN PEMBAHASAN}

Data kuantitatif diperoleh melalui tes kemampuan pemecahan masalah matematis di awal dan di akhir pembelajaran, serta pengisian skala selfconcept di awal dan di akhir pembelajaran. Data tersebut di dapat dari 62 orang mahasiswa, terdiri dari 31 mahasiswa kelas eksperimen yang mendapat pembelajaran dengan pendekatan open-ended dan 31 mahasiswa kelas kontrol yang mendapat pembelajaran konvensional. Berikut ini uraian hasil dari penelitian yang diperoleh.

Tabel 1. Perolehan Skor Rata-Rata, Deviasi Standar, dan Gain

\begin{tabular}{ccccc}
\hline \multirow{2}{*}{ Kelas } & Tes & $\begin{array}{c}\text { Skor } \\
\text { ideal }\end{array}$ & $\bar{x}$ & SD \\
\hline \multirow{3}{*}{ Eksperimen } & Pretest & 80 & 9,68 & 4,27 \\
\cline { 2 - 5 } & Posttest & 80 & 64,19 & 7,76 \\
\cline { 2 - 5 } Konvensional & $\langle g\rangle$ & & 0,78 & 0,10 \\
\cline { 2 - 5 } & Pretest & 80 & 9,94 & 5,92 \\
\cline { 2 - 5 } & Posttest & 80 & 44,51 & 8,98 \\
\hline
\end{tabular}

a) Data Kemampuan Pemecahan Masalah Matematis

Data kemampuan pemecahan masalah matematis diperoleh melalui pre-test dan post-test. Skor pre-test dan post-test selanjutnya dihitung gain (n-gain) kemampuan pemecahan masalah matematis baik pada kelas eksperimen dan kelas konvensional. Berdasarkan dari hasil pre-test dan post-test, maka didapatkan skor rata-rata, deviasi standar, dan gain kelas eksperimen dan gain kelas konvensional yang dapat dilihat pada Tabel 1.

b) Data Self-Concept

Data self-concept mahasiswa diperoleh melalui penyebaran skala self-concept kepada mahasiswa sebelum dan sesudah pembelajaran pada kelas eksperimen maupun pada kelas konvensional.

Untuk mengidentifikasi tinggi rendahnya nilai self-concept mahasiswa pada pembelajaran kelas eksperimen dan kelas konvensional ditentukan berdasarkan pada kriteria nilai minimal ideal, maksimal ideal dan median ideal. Karena skala selfconcept yang digunakan pada kelas eksperimen dan kelas konvensional sama, maka nilai minimal ideal, maksimal ideal dan median ideal pada kedua kelas juga sama. Berikut ini merupakan deskripsi nilai minimal ideal, maksimal ideal dan median ideal self-concept mahasiswa pada kelas eksperimen dan kelas konvensional. 
ISSN 2089-8703 (Print) Vol. 6, No. 2 (2017)

ISSN 2442-5419 (Online)

Tabel 2. Deskripsi Skor Self-Concept Mahasiswa

\begin{tabular}{|l|c|c|c|}
\hline \multicolumn{1}{|c|}{ Aspek } & Min $_{\text {id }}$ & Mak $_{\text {id }}$ & Med $_{\text {id }}$ \\
\hline $\begin{array}{l}\text { Pengetahuan mengenai apa } \\
\text { yang diketahui peserta didik } \\
\text { tentang matematika }\end{array}$ & 6 & 24 & 15 \\
\hline $\begin{array}{l}\text { Pengharapan pandangan } \\
\text { peserta didik tentang } \\
\text { pembelajaran matematika } \\
\text { yang ideal }\end{array}$ & 7 & 28 & 17,5 \\
\hline $\begin{array}{l}\text { Penilaian seberapa besar } \\
\text { peserta didik menyukai } \\
\text { matematika }\end{array}$ & 6 & 24 & 15 \\
\hline
\end{tabular}

Kecenderungan nilai self-concept didasarkan pada nilai Median ideal dengan ketentuan sebagai berikut:

Rekapitulasi hasil kecenderungan nilai self-concept mahasiswa ditinjau dari aspeknya dirangkum dalam Tabel 3.

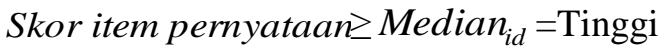

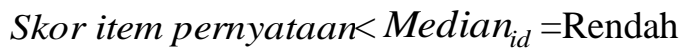

Tabel 3. Self-Concept Mahasiswa Ditinjau dari Aspeknya

\begin{tabular}{|c|c|c|c|c|c|c|}
\hline Kelas & \multicolumn{3}{|c|}{ Eksperimen } & \multicolumn{3}{c|}{ Konvensional } \\
\hline Aspek & Pretest & Posttest & Kategori & Pretest & Posttest & Kategori \\
\hline $\begin{array}{c}\text { Pengetahuan } \\
\text { mengenai apa yang } \\
\text { diketahui peserta didik } \\
\text { tentang matematika }\end{array}$ & $48,4 \%$ & $80,6 \%$ & Tinggi & $54,8 \%$ & $74,2 \%$ & Tinggi \\
\hline $\begin{array}{c}\text { Pengharapan } \\
\text { pandangan peserta } \\
\text { didik tentang } \\
\text { pembelajaran } \\
\text { matematika yang ideal }\end{array}$ & $51,6 \%$ & $90,3 \%$ & Tinggi & $41,9 \%$ & $61,3 \%$ & Tinggi \\
\hline $\begin{array}{c}\text { Penilaian seberapa } \\
\text { besar peserta didik } \\
\text { menyukai matematika }\end{array}$ & $58,1 \%$ & $77,4 \%$ & Tinggi & $61,3 \%$ & $61,3 \%$ & Tinggi \\
\hline
\end{tabular}

Penelitian ini menghasilkan beberapa temuan yang dianalisis berdasarkan kelompok pendekatan pembelajaran (pembelajaran dengan pendekatan open-ended dan pembelajaran konvensional), kemampuan pemecahan masalah matematis, dan self-concept mahasiswa.
Berikut ini diuraikan pembahasan hasil penelitian berdasarkan masing-masing faktor tersebut.

1) Secara keseluruhan kualitas pre-test kedua kelas relatif sama, namun setelah diberikan perlakuan terjadi perkembangan kemampuan akhir (post-test) pada kelas eksperimen 
lebih tinggi dibandingkan dengan kelas konvensional. Hal ini menunjukkan bahwa pembelajaran dengan pendekatan open-ended memberikan kontribusi yang baik dalam pengembangan kemampuan pemecahan masalah matematis mahasiswa.

2) Hasil yang diperoleh berdasarkan pendekatan pembelajaran dan aspek self-concept yang digunakan memberikan gambaran bahwa pembelajaran dengan pendekatan open-ended memberikan kontribusi yang baik dalam meningkatkan kemampuan pemecahan masalah matematis dan self-concept calon guru matematika, sehingga dapat disimpulkan bahwa pembelajaran matematika dengan pendekatan open-ended mempunyai peranan yang baik dalam meningkatkan kemampuan pemecahan masalah matematis dan self-concept calon guru matematika.

\section{KESIMPULAN DAN SARAN}

Hasil penelitian ini menunjukkan beberapa kesimpulan sebagai berikut:

1. Peningkatan kemampuan pemecahan masalah matematis mahasiswa yang memperoleh pembelajaran dengan pendekatan open-ended lebih baik daripada mahasiswa yang memperoleh pembelajaran konvensional.

2. Kualitas peningkatan kemampuan pemecahan masalah matematis pada kelompok mahasiswa yang memperoleh pembelajaran dengan pendekatan open-ended termasuk ke dalam kategori tinggi, sedangkan kelompok siswa yang memperoleh pembelajaran konvensional termasuk ke dalam kategori sedang.

3. Peningkatan self-concept mahasiswa yang memperoleh pembelajaran dengan pendekatan open-ended lebih baik daripada mahasiswa yang memperoleh pembelajaran konvensional.

4. Kualitas peningkatan self-concept mahasiswa yang memperoleh pembelajaran dengan pendekatan open-ended dilihat berdasarkan aspek-aspek self-concept termasuk ke dalam kategori tinggi dibandingkan dengan kelompok mahasiswa yang memperoleh pembelajaran konvensional.

Beberapa saran atau rekomendasi yang dapat dikemukakan antara lain:

1. Kemungkinan adanya kendalakendala pelaksanaan pembelajaran dengan pendekatan open-ended yang perlu diantisipasi oleh guru, diantaranya siswa belum terbiasa mengerjakan soal-soal yang mempunyai lebih dari satu cara ataupun mempunyai lebih dari jawaban. Pendidik disarankan agar terlebih dahulu menjelaskan caracara atau metode-metode yang berbeda dalam menyelesaikan soal dan mempersiapkan perangkat yang diperlukan sebelum dilaksanakannya pembelajaran.

2. Untuk materi-materi tertentu, penggunaan pendekatan open-ended masih terbuka peluang untuk melakukan penelitian lanjutan pada jenjang dan materi lain, misalnya jenjang SMP atau SMA pada kelas berbeda dan pada materi yang relevan, seperti materi tentang matriks dan statistika.

3. Penelitian ini hanya terbatas untuk meningkatkan kemampuan pemecahan masalah matematis mahasiswa. Ada baiknya peneliti selanjutnya dapat menerapkan pembelajaran dengan pendekatan open-ended untuk meningkatkan kemampuan pemahaman, 
komunikasi, penalaran, koneksi dan kemampuan-kemampuan matematis yang lain.

4. Penelitian ini hanya terbatas untuk meningkatkan self-concept mahasiswa. Masih banyak aspek psikologi lainnya yang menarik untuk diteliti berkaitan dengan prestasi dan hasil belajar siswa, seperti self-efficacy, self-esteem, kemandirian belajar, dan aspek psikologi lainnya.

\section{DAFTAR PUSTAKA}

Lambertus, Arapu, L. \& Patih, T. 2013. Penerapan Pendekatan Open-Ended Untuk Meningkatkan Kemampuan Berfikir Matematis Siswa SMP. Jurnal Pendidikan Matematika. Vol. 4, No.1, Hal 73-82.

Muchlis, E.E. 2012. Pengaruh Pendekatan Pendidikan Matematika Realistik Indonesia (PMRI) Terhadap Perkembangan Kemampuan Pemecahan Masalah Siswa Kelas II SD Kartika 1.10 Padang. Jurnal Exacta, Vol. 10, No. 2, Hal 136-139.

Nuryati, N. 2009. Meningkatkan Kemampuan Pemahaman dan Pemecahan Masalah Matematik Mahasiswa melalui Pembelajaran Inkuiri. Tesis pada SPs UPI: Tidak diterbitkan.

Rahman, R. 2012. Hubungan Antara Self-Concept Terhadap Matematika dengan Kemampuan Berfikir Matematik Siswa. Jurnal Infinity, Vol. 1, No. 1, Hal 1-11.

Uhti. 2011. Pembelajaran Kooperatif dengan Pendekatan Open-Ended Untuk Meningkatkan Kemampuan
Pemecahan Masalah Matematis Siswa Sekolah Menengah. Makalah pada Seminar Nasional Matematika dan Pendidikan Matematika, Yogyakarta.

Widjajanti, D.B. 2008. Kemampuan Pemecahan Masalah Matematis Mahasiswa Calon Guru Matematika: Apa dan Bagaimana Mengembangkannya. Makalah pada Seminar Nasional Matematika dan Pendidikan Matematika, Yogyakarta.

Widodo, P.B. 2006. Reliabilitas dan Validitas Konstruk Skala Konsep Diri Untuk Mahasiswa Indonesia. Jurnal Psikologi Universitas Dipenogoro, Vol. 3, No. 1, Hal 1-9. 